Jurnal Hukum Mimbar Justitia

Fakultas Hukum Universitas Suryakancana

Vol. 3 No. 1 - Juni 2017 p. 17-34

ISSN: 2477-5681 (Cetak), ISSN: 2580-0906 (Online)

Open Access at: http://jurnal.fhukum.unsur.ac.id/ojs/

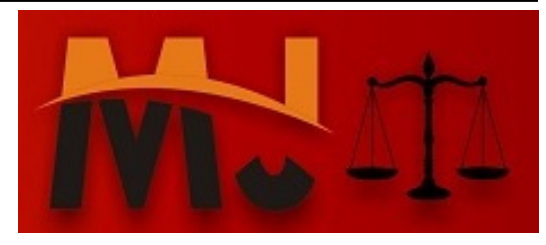

\title{
KEBIJAKAN HUKUM TERHADAP PELAKSANAAN PENGAMPUNAN \\ PAJAK (TAX AMNESTY) DALAM MENINGKATKAN \\ KESEJAHTERAAN MASYARAKAT \\ BANGSA INDONESIA
}

\author{
Mia Amalia \\ Fakultas Hukum Universitas Suryakancana \\ E-mail: amalia.amalia84@gmail.com
}

\begin{tabular}{|l|l|l|} 
Masuk: Maret 2017 & Penerimaan: Maret 2017 & Publikasi: Juni 2017 \\
\hline
\end{tabular}

\begin{abstract}
ABSTRAK
Pengampunan pajak (tax amnesty) seringkali dijadikan alat untuk menghimpun penerimaan negara dari sektor pajak (tax revenue) secara cepat dalam jangka waktu yang relatif singkat. Program tax amnesty dilaksanakan karena semakin parahnya upaya penghindaran pajak. Kebijakan ini memperoleh manfaat perolehan dana, terutama kembalinya dana yang disimpan di luar negeri, dan kebijakan ini dalam jangka panjang berakibat buruk. Menurunnya kepatuhan sukarela (voluntary compliance) dari wajib pajak patuh, bilamana tax amnesty dilaksanakan dengan program yang tidak tepat, dan memberikan gambaran mengenai pelaksanaan tax amnesty di beberapa negara relatif lebih berhasil dalam melaksanakan kebijakan pengampunan pajak. Dalam penulisan ini menganalisis faktor-faktor yang menyebabkan program ini dapat berhasil dan mencapai target yang ditetapkan dalam mewujudkan kesejahteraan bagi masyarakat bangsa Indonesia.
\end{abstract}

Kata Kunci: Kebijakan; Tax Amnesty; Penerimaan Negara; Kepatuhan Sukarela;

Kesejahteraan Masyarakat.

\begin{abstract}
Tax amnesty is often used as a media in gathering state revenues from the tax sectors in a relatively short period of time. This program is implemented because of the tax worsening evasion effort. This policy create benefits funds, especially the returning of overseas deposits, and this policy has long term bad effect. The voluntary compliance from taxpayers decrease, when tax amnesty is implemented inappropriately, and gives an idea that the implementation of tax amnesty in some countries is relatively successful in implementing tax forgiveness. This paper analyzes the factors that caused the success and achieves the targets in realizing the welfare for the Indonesian community.
\end{abstract}

Keywords: Policy; Tax Amnesty; State Revenue; Voluntary Compliance; Public welfare 


\section{PENDAHULUAN}

Pertumbuhan ekonomi nasional dalam beberapa tahun terakhir cenderung mengalami perlambatan yang berdampak pada turunnya penerimaan pajak dan juga telah mengurangi ketersediaan likuiditas dalam negeri yang sangat diperlukan untuk meningkatkan pertumbuhan ekonomi Indonesia. Di sisi lain, banyak harta warga negara Indonesia yang ditempatkan di luar wilayah Negara Kesatuan Republik Indonesia, baik dalam bentuk likuid maupun nonlikuid, yang seharusnya dapat dimanfaatkan untuk menambah likuiditas dalam negeri yang dapat mendorong pertumbuhan ekonomi nasional. ${ }^{1}$

Permasalahannya adalah bahwa sebagian dari harta yang berada di luar wilayah Negara Kesatuan Republik Indonesia tersebut belum dilaporkan oleh pemilik Harta dalam Surat Pemberitahuan Tahunan Pajak Penghasilannya sehingga terdapat konsekuensi perpajakan yang mungkin

1 Brotodihardjo R. Santoso, Pengantar Hukum Pajak, Refika Aditama, Bandung, 1998, hlm. 89. timbul apabila dilakukan pembandingan dengan harta yang telah dilaporkan dalam Surat Pemberitahuan Tahunan Pajak Penghasilan yang bersangkutan. Hal ini merupakan salah satu faktor yang menyebabkan para pemilik harta tersebut merasa ragu untuk membawa kembali atau mengalihkan harta mereka dan untuk menginvestasikannya dalam kegiatan ekonomi di Indonesia. Selain itu, keberhasilan pembangunan nasional sangat didukung oleh pembiayaan yang berasal dari masyarakat, yaitu penerimaan pembayaran pajak. Agar peran serta ini dapat terdistribusikan dengan merata tanpa ada pembeda, perlu diciptakan sistem perpajakan yang lebih berkeadilan dan berkepastian hukum. ${ }^{2}$

Hal ini didasarkan pada masih maraknya aktivitas ekonomi di dalam negeri yang belum atau tidak dilaporkan kepada otoritas pajak. Aktivitas yang tidak dilaporkan tersebut mengusik rasa keadilan bagi para Wajib Pajak yang

2 Subiyantoro, Heru dan Riphat, Singgih, Kebijakan, Fiskal, Pemikiran Konsep dan Implementasi, Penerbit Buku Kompas, 2004, hlm. 121. 
telah berkontribusi aktif dalam melaksanakan kewajiban perpajakan karena para pelakunya tidak berkontribusi dalam pembiayaan pembangunan nasional. Untuk itu, perlu diterapkan langkah khusus dan terobosan kebijakan untuk mendorong pengalihan harta ke dalam wilayah Negara Kesatuan Republik Indonesia sekaligus memberikan jaminan keamanan bagi warga negara Indonesia yang ingin mengalihkan dan mengungkapkan harta yang dimilikinya dalam bentuk Pengampunan Pajak. ${ }^{3}$

Terobosan kebijakan berupa Pengampunan Pajak atas pengalihan Harta ini juga didorong oleh semakin kecilnya kemungkinan untuk menyembunyikan kekayaan di luar wilayah Negara Kesatuan Republik Indonesia karena semakin transparannya sektor keuangan global dan meningkatnya intensitas pertukaran informasi antarnegara. Kebijakan Pengampunan Pajak dilakukan dalam bentuk pelepasan hak negara untuk menagih pajak yang seharusnya terutang.

3 Ibid., hlm. 122.
Oleh karena itu, sudah sewajarnya jika Wajib Pajak diwajibkan untuk membayar uang tebusan atas pengampunan pajak yang diperolehnya. Dalam rangka pelaksanaan UndangUndang Nomor 11 tahun 2016 tentang Pengampunan Pajak, penerimaan uang tebusan diperlakukan sebagai penerimaan Pajak Penghasilan dalam Anggaran Pendapatan dan Belanja Negara. Dalam jangka pendek, hal ini akan dapat meningkatkan penerimaan pajak pada tahun diterimanya uang tebusan yang berguna bagi negara untuk membiayai berbagai program yang telah direncanakan. Dalam jangka panjang, negara akan mendapatkan penerimaan pajak dari tambahan aktivitas ekonomi yang berasal dari Harta yang telah dialihkan dan diinvestasikan di dalam wilayah Negara Kesatuan Republik Indonesia.

Dari aspek yuridis, pengaturan kebijakan Pengampunan Pajak melalui Undang-Undang tentang Pengampunan Pajak sesuai dengan ketentuan Pasal 23A Undang-Undang Dasar Negara Republik Indonesia Tahun 1945 karena berkaitan dengan penghapusan pajak yang seharusnya terutang, sanksi 
administrasi perpajakan, dan sanksi pidana di bidang perpajakan. UndangUndang ini dapat menjembatani agar Harta yang diperoleh dari aktivitas yang tidak dilaporkan dapat diungkapkan secara sukarela sehingga data dan informasi atas Harta tersebut masuk ke dalam sistem administrasi perpajakan dan dapat dimanfaatkan untuk pengawasan kepatuhan pemenuhan kewajiban perpajakan di masa yang akan datang. Kebijakan Pengampunan Pajak seyogianya diikuti dengan kebijakan lain seperti penegakan hukum yang lebih tegas dan penyempurnaan

Undang-Undang tentang Ketentuan Umum dan Tata Cara Perpajakan. ${ }^{4}$

Undang-Undang tentang Pajak Penghasilan, Undang-Undang tentang Pajak Pertambahan Nilai Barang dan Jasa dan Pajak Penjualan atas Barang Mewah, serta kebijakan strategis lain di bidang perpajakan dan perbankan. Dengan berpegang teguh pada prinsip atau asas kepastian hukum, keadilan, kemanfaatan, dan kepentingan nasional, tujuan penyusunan Undang-Undang

4 Santoso, Urip \& Justina, Setiawan, Tax amnesty dan Pelaksanaanya di Beberapa Negara: Perspektif bagi Pebisnis Indonesia, Kopertis, Volume 11 No. 2 Juli 2009, hlm. 38.
Nomor 11 Tahun 2016 tentang Pengampunan Pajak adalah sebagai berikut:

1. Mempercepat pertumbuhan dan restrukturisasi ekonomi melalui pengalihan Harta, yang antara lain akan berdampak terhadap peningkatan likuiditas domestik, perbaikan nilai tukar Rupiah, penurunan suku bunga, dan peningkatan investasi;

2. Mendorong reformasi perpajakan menuju sistem perpajakan yang lebih berkeadilan serta perluasan basis data perpajakan yang lebih valid, komprehensif, dan terintegrasi; dan

3. Meningkatkan penerimaan pajak, yang antara lain akan digunakan untuk pembiayaan pembangunan. ${ }^{5}$

Hasil penelitian ini menunjukkan bahwa penerapan Tax Amnesty di Indonesia jika dilihat dari pengalaman berbagai negara yang telah menerapkan, Indonesia masih memiliki potensi dan peluang untuk meningkatkan dana-dana masuk ke Indonesia yang cukup banyak disimpan di luar negeri. Dalam Hal ini ada beberapa hal yang dapat dijadikan

5 Ibid, hlm. 40. 
identifikasi masalah yaitu sebagai berikut: 1. Apa yang dimaksud dengan tax amnesty? 2. Bagaimana Potensi dan peluang pemanfaatan pengampunan pajak di Indonesia dalam meningkatkan kesejahteraan masyarakat bangsa Indonesia? 3. Upaya-upaya yang harus dilakukan pemerintah dalam mengoptimalkan pelaksanaan kebijakan pengampunan pajak dalam meningkatkan kesejahteraan masyarakat bangsa Indonesia?.

\section{METODE PENELITIAN}

Metode penelitian yang digunakan dalam penelitian ini adalah studi berbagai literatur yang dikumpulkan dari literatur tidak secara langsung seperti laporan tahunan dan laporan keuangan perusahaan atau laporan dari dinas perpajakan dan sebagai studi kepustakaan yang digunakan untuk landasan teoritis dalam objek penelitian. Pengambilan data dilakukan dengan memahami, menjabarkan, dan mengutip teori atau konsep dari literatur-literatur baik didasari dari buku referensi, buku penunjang, surat kabar, jurnal dan sumber lainnya yang berkaitan dengan pembahasan dalam penelitian. ${ }^{6}$

\section{HASIL PENELITIAN DAN ANALISIS}

Latar belakang pemerintah mengajukan kebijakan tax amnesty tahun 2016 yaitu yang pertama kebijakan tax amnesty harus dilihat sebagai kebijakan ekonomi yang bersifat mendasar, jadi tidak sematamata kebijakan terkait fiskal apalagi khususnya pajak. Kebijakan yang dimensinya lebih luas, kebijakan ekonomi secara umum. Pertama dari sisi pajaknya sendiri, dengan adanya tax amnesty maka ada potensi penerimaan yang akan bertambah dalam APBN baik di tahun ini atau tahun-tahun sesudahnya yang akan membuat APBN lebih sustainable. APBN lebih sustainable dan kemampuan pemerintah untuk spending atau untuk belanja juga semakin besar sehingga otomatis ini akan banyak membantu programprogram pembangunan tidak hanya

Kotler Philip dan Keller L. Kevin, Metodologi
Penelitian, Aplikasi dalam Pemasaran,
Indeks, Jakarta, 2006, hlm. 22. 
infrastruktur tapi juga perbaikan kesejahteraan masyarakat. ${ }^{7}$

Dari satu sisi adanya tax amnesty tahun 2016 ini dan seterusnya akan sangat membantu upaya pemerintah memperbaiki kondisi perekonomian, pembangunan dan mengurangi pengangguran, mengurangi kemiskinan serta memperbaiki ketimpangan. Di sisi lain, di luar fiskal atau pajaknya, dengan kebijakan amnesty ini yang diharapkan dengan diikuti repatriasi sebagian atau keseluruhan aset orang Indonesia di luar negeri maka akan sangat membantu stabilitas ekonomi makro. Apakah itu dilihat dari nilai tukar rupiah, apakah itu dilihat dari cadangan devisa, apakah itu dilihat dari neraca pembayaran atau bahkan sampai kepada likuiditas dari perbankan. Jadi kami melihat bahwa kebijakan ini sangat strategis karena dampaknya yang bersifat makro, menyeluruh dan fundamental bagi perekonomian Indonesia. $^{8}$

7 Erwin Silitonga, Makalah berjudul: Ekonomi bawah Tanah, Pengampunan Pajak dan Referendum, 2006, hlm. 28.

8 Ibid, hlm. 29.

\section{A. Pengertian Tax Amnesty}

Tax amnesty atau amnesti pajak adalah penghapusan pajak terutang, penghapusan sanksi administrasi perpajakan, penghapusan sanksi pidana pada bidang perpajakan, maupun sanksi pidana tertentu yang diharuskan membayar dengan uang tebusan. Pengampunan pajak ini objeknya bukan hanya yang disimpan di luar negeri, tetapi juga yang berasal dari dalam negeri yang laporannya tidak diberikan secara benar. ${ }^{9}$

\section{B. Kebijakan Tax Amnesty dalam Meningkatkan Kesejahteraan Masyarakat Bangsa Indonesia}

Pada tax amnesty ini terdapat beberapa kebijakan pengampunan atau amnesti yang berbeda yang dibagi dalam 3 periode. Pada periode pertama jika periode pelaporan Oktober sampai dengan Desember 2015 maka tarif yang dikenakan dari keseluruhan harta wajib adalah sebesar 3\%. Jika periode pajak yang dilaporkan bulan Januari-Juni 2016 maka tarif yang dikenakan sebanyak 5\% dan untuk periode Juli-

9 Slegman, R.A. Edwin, Essays in Taxation, New York, 1925, hlm. 181. 
Desember 2016 akan dikenakan pajak sebesar $8 \%{ }^{10}$

Dengan adanya tax amnesty atau amnesti pajak ini dapat memberikan manfaat untuk beberapa pihak, baik itu untuk pemerintah, pengembang, maupun untuk investor. Berikut ini manfaat adanya tax amnesty untuk beberapa pihak:

1. Untuk pemerintah; dengan diberlakukannya tax amnesty atau pengampunan pajak ini maka akan menambah penghasilan penerimaan baru di mana penambahannya dirasa cukup efektif dalam mengurangi penerimaan negara yang semakin berkurang. Dengan diterapkannya tax amnesty atau pengampunan pajak ini maka secara otomatis akan menarik dana yang terdapat di luar negeri ke Indonesia yang menjadikannya masuk ke dalam pencatatan untuk sumber pajak baru. Amnesti pajak yang diasumsikan oleh pemerintah sebanyak Rp.60 triliun yang tercantum pada APBN 2016.

10 Ilyas, B. Wirawan, Suhartono Rudy, Panduan Komprehensif dan Praktis Pajak Penghasilan, Lembaga Penerbit FEUI, Jakarta, 2007, hlm. 131.
Nominal tersebut berasal dari tarif tebusan sebesar 3\% dari dana yang masuk yaitu sekitar Rp.2.000 triliun;

2. Untuk pengembang; dengan diberlakukannya amnesti pajak atau pengampunan pajak ini maka akan membuat sektor properti mengalami pertumbuhan untuk tahun berikutnya. Kebijakan ini berhubungan dengan pajak yang menjadikan indikator untuk kebangkitan sebuah bisnis properti yang ada di Indonesia. Tax amnesty ini sangat dipercaya untuk memberikan sebuah pengaruh terhadap pengembang untuk dapat terus berhubungan dengan para investor. Para investor selama ini merasa tidak mau untuk menanamkan modalnya di Indonesia karena negara Indonesia mempunyai pajak properti yang tergolong sangat tinggi;

3. Untuk investor; bukan hanya dari pemerintah dan pengembang saja yang merasa senang dengan kabar ini, hadirnya tax amnesty atau pengampunan pajak ini juga sangat disambut baik oleh para investor. 
Dengan adanya tax amnesty atau pengampunan pajak ini akan memberikan keuntungan terhadap kegiatan bisnis. Amnesti pajak ini dapat membuat para konsumen serta investor untuk lebih berani lagi melakukan pembelian terhadap properti. Dengan demikian, para investor tidak merasa lagi takut untuk melakukan pembelian properti. Demikianlah uraian singkat seputar tax amnesty mulai dari pengertian, kebijakan hingga manfaat dari tax amnesty. ${ }^{11}$

Target tambahan penerimaan negara dan peningkatan basis pajak dari adanya tax amnesty ini yang pasti kalau dari segi penerimaan, 60 mungkin angka minimum lah ya bisa 60 bisa lebih. Kami melihat sebenarnya potensi uang orang Indonesia di luar negeri sangat banyak karena berbagai macam data menunjukkan, mengindikasikan, meskipun uangnya itu berasal dari Indonesia tetapi disimpannya lebih banyak di luar negeri. ${ }^{12}$

11 Forum Diskusi Ilmiah Perpajakan, Amnesti Pajak Perlu Prasyarat Tax Reform, (http://groups.yahoo.com/group/forumpajak/message/10744).

12 Sugiono, http://cafebelajar.com/sejarahperkembangan-pemungutan-pajak.html.
Jadi

melihat

potensinya sebenarnya bisa di atas 100 triliun, minimal. kemudian kalau basis pajaknya tax amnesty ini selain untuk pemilik NPWP yang sudah menjadi wajib pajak untuk memperbaiki atau mendeklarasi harta yang belum dilaporkan, ini juga bermanfaat untuk orang yang belum punya NPWP. Sehingga diharapkan dengan tax amnesty ini memberikan peluang bagi yang belum punya NPWP untuk kemudian punya NPWP dan langsung membayar sehingga dia mulai catatan sejarah, catatan pajaknya dengan clear dan tidak dengan lagi catatan masalah di masa lalu lagi. ${ }^{13}$

Target jumlah Wajib Pajak yang diharapkan bertambah angka wajib pajak sekarang cuma 27 juta. Tentunya dari program ini diharapkan naik 2 kali lipat. Tapi bukan itu yang paling penting, yang paling penting bukan jumlah Wajib Pajaknya, tetapi jumlah pajak yang dibayarkan oleh Wajib Pajaknya itu yang diharapkan bertambah. Jadi bukan sekedar, kalau itu program ekstensifikasi namanya,

Diunduh tanggal 5 Mei 2017, pukul 21.00 WIB

13 Ibid. 
tapi kalau amnesty diharapkan baik yang sudah punya NPWP atau belum itu kemudian mendeklarasikan hartanya secara jujur $100 \%$. $^{14}$

\section{Upaya Dilakukan Dalam} Melaksanakan Pengampunan Pajak Melalui Tax Amnesty dalam Meningkatkan

\section{Kesejahteraan Masyarakat Bangsa Indonesia}

Amnesty itu paling lama sampai akhir tahun ini, sangat sebentar, tidak akan lama. Jadi setelah amnesty sampai menjelang 2018 September akan melakukan program yang namanya "Voluntary Declaration".

Jadi dipersilahkan mereka melaporkan yang sama aset yang belum terlaporkan secara voluntary tapi tarifnya tarif normal, tapi diberikan tahun 2017 tanpa sanksi. Pertama tentunya tidak bisa dipungkiri ada juga kepentingan asingnya karena dengan kalau melakukan tax amnesty apalagi cukup banyak repatriasi maka akan ada beberapa negara yang selama ini diuntungkan dengan adanya uang

14 Muhammad Suwarsono, Manajemen Stratejik: Konsep dan Kasus, Penerbit AMP YKPN, Yogyakarta, 2000, hlm. 49
Indonesia di luar negeri dan kemudian harus mengalami kerugian atau dampak negatif dari adanya tax amnesty. ${ }^{15}$

Jadi mungkin mereka juga bekerja melalui berbagai cara untuk mempengaruhi opini di Indonesia, itu kemungkinan pertama. Kemungkinan yang lain adalah kemungkinan salah pengertian karena sempat di awal pernah ada ide ini adalah total amnesty, jadi langsung menghapuskan semua jenis tindak pidana. ini kami tegaskan bahwa yang ada di Undang-Undang Pegampunan Pajak sesuai namanya yang dihapuskan hanya pelanggaran di bidang pajak. Tidak lagi bisa mengampuni atau menghapuskan pelanggaran di bidang lainnya.

Kesiapan Direktorat Jenderal Pajak Kementerian Keuangan dalam pelaksanaan tax amnesty yaitu segalanya sudah disiapkan karena sebetulnya sudah antisipasi sejak bulan November-Desember tahun 2015. Jadi sudah disiapkan baik segi administrasinya, bagaimana menyimpan datanya, agar benar-benar aman rahasia, serta juga sebenarnya juga sudah

15 Forum Diskusi Ilmiah Perpajakan, Amnesti Pajak..., Op. Cit,. 
melakukan sosialisasinya secara informal kepada pembayar pajak. ${ }^{16}$

Sumber Daya Manusia (SDM) juga sudah siap karena nanti para pendaftar bisa datang langsung ke kantor pelayanan pajak yang terdekat ya jadi tidak usah jauh-jauh datang ke Jakarta segala macam, cukup ke KPP terdekat dan dari situ sudah ada booth khusus atau seksi khusus untuk menangani pengampunan pajak dan kemudian sampai suratnya di keluarkan sesuai dengan SOP-nya. Harapan kepada Direktorat Jenderal Pajak Kementerian Keuangan terkait pelaksanaan tax amnesty yaitu kepada segenap jajaran Ditjen Pajak saya harapkan semuanya bisa mendukung penuh pelaksanaan program amnesty dan yang paling penting tidak hanya menjadikan amnesty sebagai sasaran target di 2016 saja, tapi harus dijadikan sebagai landasan untuk melakukan reformasi pajak secara menyeluruh ke depannya. Jadi diharapkan dengan adanya amnesty 2016, 2017 dan seterusnya penerimaan pajak akan jauh lebih baik, data dan informasi menjadi lebih akurat sehingga pada akhirnya

16 lbid,. tidak perlu lagi ada isu terkait kekurangan penerimaan pajak ataupun isu terkait gangguan terhadap iklim usaha sebagai akibat pemeriksaan pajak yang berlebihan. ${ }^{17}$

Arti secara sederhana dari tax amnesty adalah pengampunan pajak, yaitu adanya penghapusan pajak bagi Wajib Pajak (WP) yang menyimpan dananya di luar negeri dan tidak memenuhi kewajibannya dalam membayar pajak dengan imbalan menyetor pajak dengan tarif lebih rendah. Dengan dilakukannya tax amnesty ini, diharapkan para pengusaha yang menyimpan dananya di luar negeri akan memindahkan dananya di Indonesia dan menjadi WP baru yang patuh sehingga dapat meningkatkan pendapatan pajak negara. Dari pemberitaan $\mathrm{CNN}$ Indonesia dinyatakan bahwa banyak orang kaya di Indonesia yang menyimpan uang mereka di luar negeri, seperti Singapura, dengan memanfaatkan tax treaty. Oleh karena itulah Direktorat Jenderal Pajak (DJP) mendorong diberlakukannya tax amnesty ini untuk menarik kembali

17 Mulyo Agung, Teori dan Aplikasi Perpajakan Indonesia, Penerbit Dinamika IImu, Jakarta, 2007, hlm. 21. 
uang milik warga Indonesia yang disimpan di luar negeri. Indonesia pernah memberlakukan tax amnesty pada tahun 1984, tetapi pelaksanaannya tidak efektif karena respon WP sangat kurang dan tidak diikuti dengan reformasi sistem administrasi perpajakan secara menyeluruh. Oleh karena itu, pelaksanaan tax amnesty kali ini harus dilaksanakan secara hati-hati dan dipersiapkan secara matang. Perlunya dukungan dan persetujuan masyarakat secara penuh dan adanya landasan hukum yang memadai juga menjadi faktor penting keberhasilan pelaksanaan tax amnesty ini. ${ }^{18}$

Pada tahun 2008, pemerintah pernah menerbitkan aturan Sunset Policy yang diberlakukan selama 14 bulan per Januari 2008. Aturan Sunset Policy ini bisa dibilang merupakan versi mini dari tax amnesty. Sunset Policy adalah kebijakan pemerintah dalam menerapkan penghapusan sanksi administrasi bagi WP yang kurang bayar maupun melakukan kesalahan dalam pengisian Surat Pemberitahuan (SPT) tahunan PPh. Kebijakan versi mini dari tax amnesty ini telah berhasil

18 Ibid, hlm 42. menambah jumlah penerimaan $\mathrm{PPh}$ sebesar Rp7,46 triliun. Terjadi pro dan kontra penambahan aturan mengenai tax amnesty ini. Pendapat pro mengatakan bahwa kebijakan tax amnesty bisa menjadi solusi yang efektif untuk meningkatkan jumlah WP baru dan penerimaan pajak. Namun, terdapat kontra yang berargumen bahwa kebijakan tersebut merupakan langkah putus asa dari pemerintah. Selain itu, pemberlakuan tax amnesty dapat mendorong warga yang selama ini taat pajak menjadi nakal karena adanya faktor-faktor salah satunya adalah kecemburuan. ${ }^{19}$

Bagi banyak Negara, pengampunan pajak (tax amnesty) seringkali dijadikan alat untuk menghimpun penerimaan negara dari sektor pajak (tax revenue) secara cepat dalam jangka waktu yang relatif singkat. Program tax amnesty ini dilaksanakan karena semakin parahnya upaya penghindaran pajak. Kebijakan ini dapat memperoleh manfaat perolehan dana, terutama kembalinya dana yang disimpan di luar negeri, dan kebijakan ini dalam jangka

19 Santoso, Urip \& Justina, Setiawan, Tax Amnesty dan Pelaksanaanya..., Op. Cit, hlm. 40. 
panjang dapat berakibat buruk berupa menurunnya kepatuhan sukarela (voluntary compliance) dari wajib pajak patuh, bilamana tax amnesty dilaksanakan dengan program yang tidak tepat. Dalam hal ini memberikan gambaran mengenai pelaksanaan tax amnesty di beberapa negara yang relatif lebih berhasil dalam melaksanakan kebijakan pengampunan pajak seperti di Afrika Selatan, Irlandia dan India, dengan maksud untuk mempelajari kebijakan dari masing-masing negara serta menganalisis faktor-faktor yang menyebabkan program ini dapat ditetapkan, serta perspektifnya bagi pebisnis Indonesia. $^{20}$

Keberhasilan pelaksanaan sistem pemungutan pajak bergantung pada dua hal yaitu kesadaran masyarakat sebagai pembayar pajak dan keefektifan Pemerintah dalam penyuluhan dan pengawasan fenomena di negara yang sedang berkembang adalah adanya upaya penghindaran pajak sehingga setiap tahun pemerintah kehilangan potensi pajak yang cukup besar dari berbagai jenis pajak. Upaya

20 Ibid, hlm. 41.

penghindaran pajak dapat dilakukan dengan Dua cara yaitu tax avoidance dan tax evasion. Tax avoidance dilakukan dengan memanfaatkan celahcelah (loopholes) dari undang-undang dan peraturan pajak, tax evasion merupakan penghindaran pajak yang bertentangan dengan ketentuan perpajakan yang berlaku, jika ditemukan dalam pemeriksaan pajak akan diberi sanksi sesuai ketentuan yang berlaku. Salah satu pekerjaan pemerintah yang belum selesai saat ini adalah pengampunan pajak (selanjutnya: tax amnesty) Secara menyeluruh. ${ }^{21}$

Dalam pembahasan DPR banyak kontroversi mengenai perlu atau tidaknya memberlakukan tax amnesty. Alasan bagi yang tidak setuju adalah: tax amnesty berarti pemerintah mengakui adanya pelarian modal ke luar negeri, yang diduga sebagian merupakan hasil korupsi. Bagi mereka yang setuju: dengan tax amnesty yang dilaksanakan secara baik maka dana yang disimpan di luar negeri akan

21 Tulus Tambunan, Perdagangan Internasional dan Neraca Pembayaran, Teori dan Temuan Empiris, LP3ES, Jakarta, 2000, hlm. 39. 
kembali ke Indonesia, dapat menghasilkan tambahan penerimaan pajak yang cukup signifikan untuk menopang APBN serta dapat memberikan kesempatan kepada wajib pajak yang belum patuh menjadi wajib pajak yang patuh dan memperbaiki citra negatif aparat pajak yang melekat di kalangan masyarakat. Diharapkan ada suatu kehidupan baru yang saling percaya antara aparat pajak dan wajib pajak, dampaknya meningkatkan kepatuhan sukarela (voluntary compliance) karena adanya pengawasan yang makin efektif dan penegakan hukum (law enforcement) yang tidak pandang bulu. Telah banyak negara dengan program tax amnesty: Argentina, Australia, Belgia, Kolumbia, Ekuador, Perancis, Honduras, India, Irlandia, Italia, Panama, Philipina, dan Amerika Serikat. Denmark, Meksiko, Negeri Belanda, Norwegia, Peru Swedia dan Jerman Bara tahun 1980-an menyelenggarakan program tax amnesty berupa penghapusan hukuman denda. ${ }^{22}$

\footnotetext{
22 Usuf, A, Harry, dalam www.pajak2000.com/news_print.php. Diunduh tanggal 3 Mei 2017, pukul 20.30 WIB.
}

Bagi para wajib pajak yang secara sukarela bersedia mengungkapkan berbagai kesalahan atau penggelapan informasi yang pernah mereka lakukan di Masa lalu. Tax amnesty memungkinkan orang pribadi atau badan untuk melunasi kewajiban pajak yang sebelumnya tidak mereka penuhi, tanpa harus terkena ancaman dari beberapa atau seluruh hukuman keuangan atau kurungan badan yang biasanya berlaku jika terjadi penggelapan pajak kebijakan yang ditempuh oleh pemerintah suatu negara tujuan jangka panjangnya yaitu peningkatan jumlah wajib pajak dan peningkatan kepatuhan sukarela tax amnesty lazimnya hanya bagi pajak yang belum atau kurang bayar, berasal dari penghasilan yang belum dilaporkan dalam SPT WP baik orang pribadi maupun badan. Atas pengungkapan ini dikenakan penalti hukuman. ${ }^{23}$

Dampak pemberlakuan tax amnesty memang bisa membantu untuk memajukan Indonesia, tetapi bagi masyarakat kecil kebijakan ini dinilai tidak adil. Menurut mereka yang membayar pajak sesuai dengan ketentuan merasa diperlakukan tidak

23 Ibid,. 
adil karena kebijakan tax amnesty sejatinya adalah pengampunan pajak bagi orang-orang kaya yang melakukan segala cara untuk menghindari membayar pajak. Pemasukan pajak yang akan didapatkan dari pemberlakuan tax amnesty juga dinilai tidak seimbang dengan besarnya sanksi yang seharusnya diberlakukan kepada mereka yang mengemplang pajak. ${ }^{24}$

\section{Jadi kebijakan tax amnesty} memang bisa jadi cara yang efektif bagi pemerintah untuk meningkatkan kesadaran pajak di seluruh lapisan masyarakat tetapi harus dibarengi dengan penyelesaian sistem perpajakan Indonesia yang masih menumpuk. Akhir-akhir ini, sering mendengar celotehan mengenai Pengampunan Pajak. Seluruh lapisan masyarakat, baik muda atau tua, baik pekerja atau pengusaha, baik pejabat ataupun warga sipil, semuanya terfokus dalam pelaksanaan dengan adanya pengampunan pajak. Banyak isu yang berkembang mengenai pengampunan pajak. Masih banyak masyarakat yang

24 Brotodihardjo R. Santoso, Pengantar Hukum Pajak..., Op. Clt, hlm. 43. bingung, sebenarnya perlu ikut pengampunan pajak atau tidak. ${ }^{25}$

Pengampunan Pajak sendiri bukan merupakan kewajiban setiap Wajib Pajak. Pengampunan pajak merupakan hak yang bisa diperoleh oleh Wajib Pajak yang lupa melaporkan hartanya. Pengampunan Pajak berhak diajukan oleh perorangan ataupun badan usaha seperti PT. Perorangan baik pebisnis, wiraswasta, maupun karyawan berhak ikut pengampunan pajak. Lalu apa bedanya jika ikut Pengampunan Pajak dengan tidak ikut Pengampunan Pajak? Jika ikut Pengampunan Pajak:

1. Setiap Warga Negara Indonesia berhak mengikuti program Pengampunan Pajak dan jika memutuskan mengikuti program Pengampunan Pajak maka si wajib pajak tidak boleh melakukan pembetulan SPT lagi terhitung dari SPT tahun 2015;

2. Untuk mengikuti Pengampunan Pajak, Wajib Pajak dapat mengungkapkan harta yang selama ini belum dilaporkan kemudian membayar uang tebusan atas harta

25 Sadono Sukirno, Pengantar Teori Makro Ekonomi, Edisi ke-2, PT. Raja Grafindo Persada, Jakarta, 1997, hlm. 29. 
tersebut. Tarif uang tebusan sendiri berbeda-beda tergantung periode dan jenis Pengampunan Pajak yang dilakukan Wajib Pajak, mulai dari 2\% (dua persen) sampai dengan $10 \%$ (sepuluh persen). Khusus untuk UMKM, tarifnya adalah 0,5\% ( nol koma lima persen ) dan 2\% (dua persen);

3. Pengampunan Pajak yang ada berupa penghapusan pajak yang seharusnya terutang serta pembebasan sanksi administrasi dan sanksi pidana perpajakan;

4. Jika sudah ikut Pengampunan Pajak, atas harta yang dilaporkan tidak akan diperiksa lagi di masa depan;

5. Jika ikut Pengampunan Pajak, maka akan dilakukan penghentian pemeriksaan pajak, pemeriksaan bukti permulaan, dan penyidikan tindak pidana di bidang perpajakan, dalam hal Wajib Pajak sedang dilakukan pemeriksaan pajak, pemeriksaan bukti permulaan, dan penyidikan tindak pidana di bidang perpajakan;

6. PPh Final atas pengalihan harta berupa tanah dan/atau bangunan serta saham akan dihapuskan jika Wajib Pajak ikut Pengampunan Pajak;

7. Jika ikut Pengampunan Pajak dan di kemudian hari ditemukan harta yang tidak dilaporkan di dalam periode pengampunan pajak yakni harta per 31 Desember 2015 , maka temuan harta tersebut akan dikenakan tarif pajak sebesar 30 (tiga puluh) persen (tarif $\mathrm{PPh}$ pribadi yang berlaku) dan sanksi denda sebesar 200\% (dua ratus persen).

Jika tidak ikut pengampunan pajak: Wajib Pajak dengan kemauan sendiri dapat membetulkan Surat Pemberitahuan Tahunan (SPT) dengan menyampaikan pernyataan tertulis. ${ }^{26}$ Syaratnya, Direktur Jenderal Pajak belum melakukan tindakan pemeriksaan:

1. Jika pembetulan yang dilakukan mengakibatkan adanya penambahan utang pajak, maka Wajib Pajak dikenai sanksi administrasi berupa bunga sebesar $2 \%$ per bulan atas jumlah pajak yang kurang dibayar. Ini terhitung sejak saat

Santoso, Urip \& Justina, Setiawan, Tax amnesty dan Pelaksanaanya..., Op.Clt., hlm. 39. 
penyampaian SPT berakhir sampai dengan tanggal pembayaran dan bagian dari bulan dihitung penuh satu bulan;

2. Jika Wajib Pajak telah memiliki NPWP sebelum tahun 2015 atau sebelumnya, dan belum melaporkan SPT Tahunan PPh 2015, maka Wajib Pajak dapat melaporkan hartanya tanpa ikut Pengampunan Pajak dan hanya dikenai Sanksi telat lapor sebesar Rp 100.000 (bagi WP Orang Pribadi) asalkan atas penambahan harta tersebut tidak menyebabkan timbulnya tambahan utang pajak;

3. Aset yang dilaporkan dalam pembetulan SPT tersebut masih bisa diperiksa di masa depan;

4. Jika tidak ikut Pengampunan Pajak dan di kemudian hari ditemukan harta yang tidak dilaporkan di dalam periode pengampunan pajak yakni harta per 31 Desember 2015 , maka temuan harta tersebut akan dikenakan sanksi sebesar 30 persen (tarif $\mathrm{PPh}$ pribadi yang berlaku) dan sanksi bunga sebesar 2 persen perbulan maksimal 24 bulan atau maksimal 48 persen. $^{27}$

\section{PENUTUP}

Dalam uraian ini diuraikan kesimpulan sebagai berikut:

1. Pengertian tax amnesty adalah pengampunan atau pengurangan pajak terhadap properti yang dimiliki oleh perusahaan yang akan segera diatur dalam UndangUndang Pengampunan Nasional. Hal-hal yang berkaitan dengan Undang-Undang Nomor 11 Tahun 2016 tentang Pengampunan Pajak dikatakan bahwa pengampunan pajak adalah penghapusan pajak terutang, penghapusan sanksi administrasi perpajakan, penghapusan sanksi pidana pada bidang perpajakan, maupun sanksi pidana tertentu yang diharuskan membayar dengan uang tebusan.

2. Kebijakan manfaat yang diambil dalam melakukan perintah melaksanakan tax amnesty adalah kebijakan ini memiliki potensi yang cukup besar dan berpengaruh positif bagi pasar bursa efek Indonesia, di mana akan terjadi penambahan emiten baru karena perusahaan-perusahaan tidak perlu khawatir atas permasalahan pajak yang telah lewat. Karena masalah perpajakan merupakan salah satu faktor yang dianggap memberatkan 
bagi calon emiten untuk mengubah status perusahaannya.

3. Upaya-upaya yang harus dilakukan pemerintah dalam mengoptimalkan pajak, Indonesia harus terlebih dahulu melakukan program sosialisasi ke seluruh lapisan masyarakat luas dengan strategi yang tepat dan terarah agar masyarakat mengerti tujuan diadakannya kebijakan pengampunan pajak ini.

Adapun saran yang dapat penulis sampaikan adalah sebagai berikut:

1. Ada beberapa langkah yang ditempuh pemerintah Indonesia khususnya Direktorat Jenderal Pajak guna meningkatkan penerimaan negara dari sektor pajak, antara lain melaksanakan program Sensus Pajak Nasional;

2. Selain itu melakukan penyempurnaan peraturan untuk menangani tindakan penghindaran pajak (tax avoidance), tindakan penggelapan pajak melalui transfer pricing, dan pengenaan pajak final;

3. Adanya upaya dalam pembenahan internal aparatur dan sistem perpajakan. Adanya reformasi dan penataan sistem perpajakan dilakukan dengan baik yaitu perbaikan potensi, intensifikasi dan ekstensifikasi, pengembangan teknologi informasi, perbaikan sumber daya manusia serta pengawasan;

4. Tax amnesty dapat diimplementasikan di Indonesia, namun harus mempunyai payung hukum sebagai dasar serta tujuan yang jelas dalam pelaksanaan tax amnesty;

5. Salah satu kelemahan tax amnesty jika diterapkan di Indonesia adalah dapat mengakibatkan berbagai penyelewengan dan moral hazard karena sarana dan prasarana, keterbukaan akses informasi serta pendukung lainnya belum memadai sebagai prasyarat pemberlakuan tax amnesty tersebut;

6. Implementasi tax amnesty dalam jangka pendek sebaiknya ditunda terlebih dahulu menunggu kesiapan berbagai perangkat dan piranti hukum yang melandasi pelaksanaan kebijakan ini. Namun dalam rangka meningkatkan penerimaan negara pemerintah (Dirjen Pajak) dapat menerapkan kebijakan-kebijakan inovatif lainnya. 


\section{DAFTAR PUSTAKA}

\section{A. Buku}

Brotodihardjo R. Santoso, Pengantar Hukum Pajak, Refika Aditama, Bandung, 1998.

Ilyas, B. Wirawan, Suhartono Rudy, Panduan Komprehensif dan Praktis Pajak Penghasilan, Lembaga Penerbit FEUI, Jakarta, 2007.

Kotler, Philip dan Keller L. Kevin, Metodologi Penelitian, Aplikasi Dalam Pemasaran, Indeks, Jakarta, 2006.

Muhammad Suwarsono, Manajemen Stratejik: Konsep dan Kasus, Penerbit AMP. YKPN,

\section{B. Peraturan undangan}

Undang-Undang Dasar Negara Republik Indonesia Tahun 1945.

Undang-Undang Nomor 11 tahun 2016 tentang Pengampunan Pajak.

\section{Jurnal, Makalah, Internet, dan Lain-lain}

Enste, H. Dominik \& Schendik, Frederick, Shadow Economies: Size, Causes and Consequences, Journal of Economic Literature, Vol. XXXVIII March 2000, pp 77-114.

Santoso, Urip \& Justina, Setiawan, Tax amnesty dan Pelaksanaannya di Beberapa Negara: Perspektif bagi Pebisnis Indonesia, Kopertis, Volume 11 No. 2 Juli 2009.

Mulyo Agung, Teori dan Aplikasi Perpajakan Indonesia, Penerbit Dinamika Ilmu, Jakarta, 2007.

Slegman, R.A. Edwin, Essays in Taxation, New York, 1925.

Sadono Sukirno, Pengantar Teori Makro Ekonomi, Edisi ke-2, PT. Raja Grafindo Persada, Jakarta, 1997.

Subiyantoro, Heru dan Riphat, Singgih, Kebijakan, Fiskal, Pemikiran Konsep dan Implementasi, Penerbit Buku Kompas, 2004.

Tulus Tambunan, Perdagangan Internasional dan Neraca Pembayaran, Teori dan temuan Empiris, LP3ES, Jakarta, 2000.
Silitonga, Makalah berjudul: Ekonomi bawah Tanah, Pengampunan Pajak dan Referendum, 2006.

Forum Diskusi Ilmiah Perpajakan, Amnesti Pajak Perlu Prasyarat Tax Reform, (http:/groups.yahoo.com/group/fo rum-pajak/message/10744).

Sugiono, http://cafebelajar.com/sejarahperkembangan-pemungutanpajak.html.

Usuf, A, Harry, dalam www.pajak2000.com/news_print. php. 